\title{
The Death Penalty and Democracy
}

\begin{abstract}
Many people in Japan argue that for abolition or significant death penalty reform to occur, public discussion (giron) must first change public opinion. This belief is misleading, because public opinion about capital punishment in Japan is rooted in moral intuitions about retribution and atonement that are largely impervious to rational discussion, and because death penalty abolitions and moratoria are invariably caused by political leadership from the front, not by changes in public perception. Claims that capital punishment reflects "democracy-at-work" are similarly simplistic because "democracy" means more than majority rule. If the abolition of capital punishment does occur in Japan, it will probably have several positive consequences for Japanese criminal justice and society.
\end{abstract}

Keywords Public opinion - Chiba Keiko - Marshall hypothesis • Leadership from the front - Article 9 - Representative democracy • Participatory democracy $\cdot$ Legal democracy $\cdot$ Liberal democracy

Why would an abolitionist Minister of Justice order executions? Chiba Keiko was the first of eight people to serve as Minister of Justice while the Democratic Party of Japan controlled Japan's central government between August 2009 and December 2012. She held the post for one year, and she was one of three DPJ Ministers to authorize executions. In

(C) The Author(s) 2020

D. T. Johnson, The Culture of Capital Punishment in Japan, Palgrave Advances in Criminology and Criminal Justice in Asia, https://doi.org/10.1007/978-3-030-32086-7_6 
July 2010, she ordered the hanging of two men, Shinozawa Kazuo, who was convicted of killing six persons, and Ogata Hidenori, who was convicted of killing two. In addition to signing their death warrants, Chiba attended their hangings at the gallows in Tokyo, something no modern Minister had done, and she permitted a few select journalists to view the Tokyo gallows when not in operation-a sharp break from the customary secrecy that shrouds executions in Japan. Then Chiba established a "Study Group about the State of Capital Punishment" in her Ministry of Justice, which released a report of its findings in March 2012 that included little information about the reality of execution.

These actions by Chiba-particularly the executions she orderedattracted much attention, especially from fellow abolitionists, many of whom believe she betrayed the cause of abolition. Some of her criticslawyers, politicians, and members of NGOs-expressed anger and dismay. In their view, Chiba accomplished nothing positive by ordering the executions, she violated her own beliefs about human rights and the sanctity of life, she greased the wheels of the machinery of death for her DPJ successors (two of whom would authorize executions in 2012), and she set back the cause of death penalty reform, which the DPJ said it was committed to in the campaign that culminated in its landslide victory in the summer 2009 election.

In 2016, Chiba provided her most detailed explanation for the executions that she ordered. ${ }^{1}$ It is the third explanation she has given, and it is the clearest. In the previous two explanations-an essay in the Asabi newspaper, and an interview in an NHK documentary-Chiba's words reminded me of George Orwell's observation that "The great enemy of clear language is insincerity." 2 I do not know why Chiba's third account is clearer, but I have two hunches. For one, repetition sometimes improves the clarity of an explanation (ask a teacher or preacher). For another, Horikawa Keiko, who conducted the interview of Chiba in 2016, is a master journalist who possesses a knack for telling interesting stories. Whatever the reasons, Chiba should be commended for (finally)

${ }^{1}$ Chiba Keiko, interviewed by Horikawa Keiko, “'Naze Shikko' no Toi o Kakaete” ["Engaging the Question of 'Why I Executed"'], Sekai, March 2016, pp. 160-170.

${ }^{2}$ Chiba Keiko, "Shikko no Shomei wa Watashi Narino Koishi: Shikei - Nayami Fukaki Mori", Asahi Shimbun, November 20, 2010; and "Shikei Shikko: Homu Daijin no Kunou" (NHK ETV Tokushu, broadcast on February 27, 2011). 
explaining why she authorized the hangings in 2010. She could have hidden behind silence and platitudes, as most Ministers of Justice do when it comes to capital punishment, and as most prosecutors and politicians do too. Here is what we learn from her interview with Horikawa.

1. Chiba's main reason for authorizing the executions in 2010 was to stimulate "public discussion" (giron) about capital punishment in Japan.

2. Chiba planned to authorize executions from the moment she accepted the Minister of Justice job in September 2009, some ten months before the hangings occurred.

3. Chiba does not believe the executions she authorized actually advanced public discussion.

4. Chiba does not believe the executions served victims or the cause of justice.

5. Officials in the Ministry of Justice did not pressure Chiba to sign the death warrants.

6. Chiba believes many officials in the Ministry of Justice oppose capital punishment or feel ambivalent about it.

7. Before the 2010 executions, Chiba asked officials in the Ministry for information about the reality of hanging, but they refused to give it to her.

8. Ministry of Justice officials did not try to dissuade Chiba from attending the two hangings she authorized.

9. The executions Chiba observed were so "cruel" and "hideous" that she finds them difficult to describe.

10. Chiba believes Japan is slowly moving toward the abolition of capital punishment.

All of these assertions are interesting, but I shall focus on the first, for Chiba's belief that executions would promote "public discussion" (giron) about capital punishment is surely the main point of her interview. Indeed, the term "public discussion" occurs 29 times in its 11 pages. The frequent repetition of this expression and its appearance in key parts of the text (including the subtitle of the article and the first section heading) reflects Chiba's core conviction that for significant death penalty reform to occur, public discussion must first change public opinion. 
This belief is widely shared in Japan, ${ }^{3}$ but it is misleading in at least three ways, as the following section shows. ${ }^{4}$

\section{On Public Opinion and Capital Punishment}

First, more than 140 countries have abolished the death penalty in law or have gone more than ten years in a row without an execution, yet in none of these countries did the change result from majority public opinion pushing for reform. There are few iron laws in socio-legal studies, but this may be one: when executions cease or the death penalty disappears, the primary proximate cause is leadership by political elites, despite public support for capital punishment at the time of the reform. ${ }^{5}$ This pattern of "leadership from the front" suggests that efforts to convince a majority of Japanese people to oppose capital punishment are probably doomed to fail. In this sense, public education campaigns are a hollow hope-though of course they are not irrelevant. Their primary value is their influence on the views of elite decision-makers, who are the actors with the practical ability to secure abolition or a moratorium. Still, the main lesson from the rest of the world is that "the straightest road to abolition" often involves "bypassing public opinion entirely." 6 A parallel lesson can be learned from Japan's closest cousins, South Korea and Taiwan, both of which have experienced moratoria on executions in recent years (Taiwan from 2006 through 2009, and South Korea from 1998 to the present). In both countries, the cessation of executions had "little to do with public opinion, which generally favors retaining the death penalty." ${ }^{\prime 7}$ Executions ceased primarily because political leaders wanted to stop this form of state killing.

${ }^{3}$ See, for example, Sato Mai, "Yoron to Iu Shinwa: Nozomu no wa 'Shikei' Desu ka", Sekai, March 2016, pp. 183-191.

${ }^{4}$ See also David T. Johnson, “Shikei no 'Giron' e no Gimon: Chiba moto Homu Daijin e no Intabyu o Megutte" [on the Interview of Former Minister of Justice Chiba Keiko in the March 2016 Issue of Sekai], Sekai, No. 882 (May 2016), pp. 228-235 (translated by Naoko Iwakawa and Makoto Ibusuki).

${ }^{5}$ Franklin E. Zimring, The Contradictions of American Capital Punishment (Oxford University Press, 2003), pp. 17-26.

${ }^{6}$ Andrew Hammel, Ending the Death Penalty: The European Experience in Global Perspective (Palgrave Macmillan, 2010), p. 236.

${ }^{7}$ Sangmin Bae, "International Norms, Domestic Politics, and the Death Penalty: Comparing Japan, South Korea, and Taiwan”, Comparative Politics, Vol. 44, No. 1, p. 41. 
A second stubborn fact is that public support for capital punishment in Japan is rooted in sentiments about retribution and atonement. ${ }^{8}$ As a result, the belief that death is deserved for certain heinous offenders is more a matter of emotion and intuition than reason or evidence. In this context, providing more information about capital punishment is unlikely to alter habits of the heart, for humans are adept at ignoring contrary evidence and discounting or denying its significance. ${ }^{9}$ On hot-button issues such as capital punishment and immigration, facts can even be counter-productive, for research shows that the smarter a person is, the greater his or her ability to rationalize discordant information. ${ }^{10}$ When people take the trouble to think about capital punishment at all, they often engage in post hoc justification, which tends to reinforce their bedrock beliefs in retribution and atonement.

Third, changing public opinion about capital punishment is always difficult and sometimes impossible. In a 1972 decision (Furman v. Georgia), U.S. Supreme Court Justice Thurgood Marshall famously stressed the importance of public opinion in settling questions about the constitutionality of capital punishment under the "cruel and unusual" clause of the Eighth Amendment. Justice Marshall made three connected claims: (a) most Americans lack knowledge about capital punishment; (b) the more Americans learn about capital punishment, the less they will support it; and (c) commitments to capital punishment that are rooted in retribution are especially difficult to change. In a subsequent death penalty opinion (Gregg v. Georgia in 1976), Justice Marshall stated that if the American people were better informed about capital punishment, "they would find it shocking, unjust, and unacceptable." In his view, the key question about capital punishment is not whether

\footnotetext{
${ }^{8}$ See, for example, Mari Kita and David T. Johnson, "Framing Capital Punishment in Japan: Avoidance, Ambivalence, and Atonement", Asian Journal of Criminology, Vol. 9, No. 3 (September 2014), pp. 221-240. See also Mai Sato, The Death Penalty in Japan: Will the Public Tolerate Abolition? (Springer VS, 2014); and Hamai Koichi's book review in Social Science Japan Journal (January 2015), pp. 103-106 (arguing that "there is an extremely deep-rooted belief in Japan that criminals should receive heavy penalties").

${ }^{9}$ Jonathan Haidt, The Righteous Mind: Why Good People Are Divided by Politics and Religion (Pantheon, 2012).

${ }^{10}$ Tali Sharot, The Influential Mind: What the Brain Reveals About Our Power to Change Others (Henry Holt, 2017).
} 
"a substantial proportion of American citizens would today, if polled, opine that [it] is barbarously cruel, but whether they would find it to be so in light of all information presently available" (emphasis added). The Marshall Hypothesis (as it came to be called) has been the subject of much study, and results are "decidedly mixed." Il In some studies of American attitudes, more information about capital punishment does not lead to more distaste for it. In other studies, information alters opinion for a while, but opinion eventually rebounds back to its original position. In still other studies, information persuades some people to become more opposed to capital punishment while persuading others to become more supportive of it. Research has also been done to explore the relevance of the Marshall hypothesis in Japan. In one study, when Japanese citizens were given information about capital punishment and allowed to deliberate with other people about the issue, 11 out of 50 participants shifted their support from retention to abolition, while 9 of the 50 changed their attitude in the opposite direction. ${ }^{12}$ More research is needed, but this finding suggests that "public discussion" (giron) may do little to alter overall support for capital punishment.

Before Japan's lay judge reform took effect in 2009, some analysts predicted that the new trial system would result in fewer death sentences, because citizens on lay judge panels would be forced to think deeply about the death penalty, and because (some prognosticators supposed) the harder citizens thought about it, the more reluctant they would be to support it. ${ }^{13}$ As explained in Chapter 5 , this has not happened. In fact, since 2009, lay judge panels have actually been substantially more likely to impose a sentence of death when prosecutors seek one than panels of three professional judges were in the homicide trial system that operated until 2009. ${ }^{14}$ The Marshall hypothesis also receives little

\footnotetext{
${ }^{11}$ Carol Steiker, "The Marshall Hypothesis Revisited", Howard Law Journal (2009), pp. $525-558$.

${ }^{12}$ Mai Sato, The Death Penalty in Japan: Will the Public Tolerate Abolition? (Springer VS, 2014), pp. 157-180.

${ }^{13}$ Leah Ambler, "The People Decide: The Effect of the Introduction of the QuasiJury System (Saiban-in Seido) on the Death Penalty in Japan", Northwestern Journal of International Human Rights, Vol. 6, No. 1 (Fall 2008), pp. 1-23.

${ }^{14}$ Takeda Masahiro, “Genbatsuka no Ippo de Yuyo Oku”, Kyoto Shimbun, March 23, 2019 , p. 6.
} 
support in America, where 80 percent of the citizens who serve as capital jurors do not change their mind about capital punishment, and where those who do change their mind are actually more likely to become more supportive of capital punishment than to become more opposed to it. In short, there is little empirical support for the premise about "public discussion" (giron) that motivated Minister of Justice Chiba Keiko to order executions in the summer of 2010.

Ironically, the strongest support for the Marshall hypothesis is found among the judges on the U.S. Supreme Court where Justice Thurgood Marshall served. Several American Justices who started their careers on the U.S. Supreme Court supporting capital punishment converted to anti-death penalty views after serving many years and considering many capital appeals. ${ }^{15}$ Most notably, Justices Lewis Powell, John Paul Stevens, and Potter Stewart voted in favor of capital punishment in a 1976 case (Gregg v. Georgia) that helped restart America's machinery of death after the country had gone nearly ten years without an execution. By the end of their tenures on the bench-after many years of applying the American jurisprudence of "super due process" and after the discovery of "capital error" in numerous death penalty cases-all three came to conclude that it is impossible to administer the death penalty in a manner that is consistent with the protections promised by American law. As Justice Powell remarked after his retirement, whatever attractions capital punishment might have in principle, its actual practice "serves no useful purpose and brings discredit on the whole legal system."16 Other Justices on the U.S. Supreme Court have learned a similar lesson: to love the law is to hate capital punishment. ${ }^{17}$ Indeed, the growing recognition that supports for capital punishment is inconsistent with respect for law has led some American observers to predict that eventually the U.S. Supreme Court will "conclude that capital punishment and the promise of due process of law are incompatible". ${ }^{18}$

${ }^{15}$ Evan J. Mandery, A Wild Justice: The Death and Resurrection of Capital Punishment in America (W. W. Norton, 2013), pp. 432-440.

${ }^{16}$ Quoted in Kathleen A. O'Shea, Women and the Death Penalty in the United States, 1900-1998 (Greenwood Publishing Group, 1999), p. 29.

${ }^{17}$ Austin Sarat, When the State Kills: Capital Punishment and the American Condition (Princeton University Press, 2001).

${ }^{18}$ Scott Turow, Ultimate Punishment: A Lawyer's Reflections on Dealing with the Death Penalty (Farrar, Straus and Giroux, 2003), p. 114. 
In contrast to the United States, there are three reasons why conversion against capital punishment seems unlikely to occur among Justices on Japan's Supreme Court. For one, persons appointed to that Court tend to be more conservative and less ideologically diverse than their counterparts in America. ${ }^{19}$ For another, Justices on Japan's Supreme Court serve much shorter terms than American Justices do-an average of 6 years in Japan compared with 26 years in the United States. As a result, Justices in Japan encounter fewer capital cases-and fewer occasions to find flaws in the way capital punishment is administered. Most fundamentally, since death is not "different" in Japanese law, and since "super due process" is not a legal requirement, error is seldom recognized in capital cases (see Chapter 2). By contrast, capital cases have occupied one-quarter to one-half of all state criminal cases on the U.S. Supreme Court's docket in recent years, and nearly half of American death sentences never result in execution because they are reversed on appeal for prosecutorial misconduct, ineffective assistance of counsel, flawed jury instructions, and a host of other errors. In this comparative light, Japanese jurisprudence seems to reflect a perverse principle, that if law aims low in death penalty cases, judges and the general public will seldom be disappointed.

\section{Two Qualifications}

Although "public discussion" (giron) does not drive death penalty reform, this truth must be qualified in two ways. First, the limited importance of public discussion does not mean the Japanese state should continue withholding information about capital punishment from its citizens, especially in an era when citizens are being asked to make life and death decisions in lay judge trials. As many former lay judges have observed, for saibanin to carry out their responsibilities properly, the Ministry of Justice must provide citizens with "all relevant information." 20 As explained in Chapter 3, the secrecy surrounding executions in Japan is deeply disconcerting. It is also more rooted in discretion than

${ }^{19}$ J. Mark Ramseyer and Eric B. Rasmusen, Measuring Judicial Independence: The Political Economy of Judging in Japan (University of Chicago Press, 2003).

${ }^{20}$ See for example, former lay judge Taguchi Masayoshi, "Shikei to Mukiau Shimin: Saibanin Handan no Hatsushikko o Ukete", Sekai, March 2016, pp. 194-199. 
law. Officials in the Ministry of Justice (the main architects and enforcers of this secrecy policy) can and should remove this wart from Japan's body politic. The Japanese public deserves more information about how the death penalty is administered even if increased public oversight of executions will not end them, and even if increased transparency is unlikely to change many minds about the propriety of capital punishment. Increased openness is the right thing to do.

The second qualification is that education about the death penalty is not completely futile. As mentioned above, it is most effective when it is directed at the political elites who hold the fate of capital punishment in their hands. The best scholarly work on this subject finds that "the death penalty is always and everywhere an exercise of state power." 21 In this sense, the trajectory of capital punishment is mainly determined by political actors and political processes. The cultural shifts that matter most are those that will influence the attitudes and beliefs of elites (politicians, bureaucrats, and business and legal professionals), by generating discourse among them, by weakening the intensity of support among those who favor retention, and by strengthening the intensity of opposition among those who favor abolition. To the extent that "public discussion" shapes elite opinion in these ways, it can contribute to death penalty reform. Chiba Keiko seemed to recognize this when she advocated the creation of an organ in Parliament to gather and discuss information about the death penalty. Unfortunately, she also saw political action as causally subordinate to "public discussion." Evidence from the rest of the world suggests that she got the dynamic backward.

\section{On Democracy}

In sum, belief that "public discussion" (giron) will produce death penalty reform contradicts three hard facts. Public opinion about the death penalty is difficult to change in every society. Public opinion about the death penalty in Japan is rooted in moral intuitions about retribution and atonement that are largely impervious to rational discussion. And in other countries, death penalty abolitions and moratoria have been caused by leadership from the front, not by changes in public opinion. But if

${ }^{21}$ David Garland, Peculiar Institution: America's Death Penalty in an Age of Abolition (The Belknap Press of Harvard University Press, 2010), p. 127. 
public discussion in Japan seems unlikely to lead to the end of capital punishment, what hope is there for abolition? Is "leadership from the front" undemocratic or even anti-democratic?

Richard Posner, a prominent federal judge on the U.S. Court of Appeals for the Seventh Circuit in Chicago (who retired from the bench in 2017) and the most cited American legal scholar of all time, claims that the main reason America retains capital punishment long after the developed democracies of Europe abolished it is because America is "more democratic." 22 In his view, American government is permeated with politics, and elected officials find it more necessary to implement policies supported by a majority of voters than do their elected counterparts in countries without an American-style "hyper-democracy" that stresses local decision-making, popular participation, and electoral accountability. Other analysts also conclude that America's "radically local version of democracy" helps explain the persistence of capital punishment in the United States and the "peculiar" forms it takes in many American places. ${ }^{23}$

In Japan, too, prosecutors, politicians, and the public frequently claim that capital punishment is simply an expression of democracy at work. ${ }^{24}$ On this view, death sentences and executions are the natural result of majority support for capital punishment. On this view, the death penalty is democratically ordained. And in the context of public support for capital punishment, to oppose it is to defy a central imperative of democratic governance.

Claims that capital punishment reflects "democracy-at-work" are simplistic and misleading, both empirically and theoretically. Empirically, electorates are not well-informed about many political issues, and elections seldom produce governments that are responsive to what (uninformed) voters say they want. ${ }^{25}$ What is more, research about "who rules?"

\footnotetext{
${ }^{22}$ Richard Posner, "Capital Crimes”, The New Republic, April 1, 2002, p. 32.

${ }^{23}$ See, for example, David Garland, Peculiar Institution: America's Death Penalty in an Age of Abolition (The Belknap Press of Harvard University Press), p. 309; and Andrew Hammel, Ending the Death Penalty: The European Experience in Global Perspective (Palgrave Macmillan, 2010), especially Chapter 8, "Why the European Model Failed in the United States".

${ }^{24}$ Several such claims are discussed in Nempo Shikei Haishi 2017, Popyurizumu to Shikei (Impakuto, 2017), pp. 5-64; and in Mai Sato, The Death Penalty in Japan: Will the Public Tolerate Abolition? (Springer VS, 2014).

${ }^{25}$ Christopher H. Achen and Larry M. Bartels, Democracy for Realists: Why Elections Do Not Produce Responsive Governments (Princeton University Press, 2017).
} 
in democratic countries finds that the views of average people are seldom decisive in policymaking. In the United States, for example, one study tracked how well the preferences of the public and of various groups predicted the ways that Congress and the executive branch would act on 1779 policies over a two-decade period. It found that economic elites and narrow interest groups succeeded in getting their favored policies about half the time, and they succeeded in stopping legislation to which they were opposed nearly all the time. In contrast, mass-based interest groups had little effect on public policy, while the views of ordinary citizens had virtually no effect at all. As the authors of this study concluded, "When the preferences of economic elites and the stands of organized interest groups are controlled for, the preferences of the average American appear to have only a miniscule, near-zero, statistically non-significant impact upon public policy." 26 In Japan as well, organized interest groups and economic elites continue to shape public policy even after the basic rules of the political game have changed. ${ }^{27}$

The main theoretical problem with "democracy at work" claims is that "democracy" means more than majority rule. In fact, there are at least four ways in which "democracy" and the death penalty are related, because democracy can be representative, participatory, legal, or liberal. In representative democracy, death penalty policy reflects what citizens want, as indicated in elections, public opinion polls, and other expressions of public sentiment. In participatory democracy, the administration of the death penalty allows citizens to perform certain roles in the criminal process, as witnesses, as victims and survivors with a stake in case outcomes, and as lay judges who make life-and-death decisions at trial. In legal democracy, the death penalty aims to advance the rule of law by deterring murder and by being administered in a manner that is fair, just, and accurate. And in liberal democracy, criminal punishment is supposed to advance values such as dignity, liberty, equality, and the right to life. ${ }^{28}$

\footnotetext{
${ }^{26}$ Martin Gilens and Benjamin I. Page, "Testing Theories of American Politics: Elites, Interest Groups, and Average Citizens", Perspectives on Politics, Vol. 12, No. 3 (September 2014), pp. 564-581.

${ }^{27}$ Matthew Carlson, Money Politics in Japan: New Rules, Old Practices (Lynne Rienner, 2007).

${ }^{28}$ This analysis relies on the fine work of Maximo Langer and David Alan Sklansky, editors, Prosecutors and Democracy: A Cross-National Study (Cambridge University Press, 2017).
} 
As guides for thinking about what democracy requires, these four themes can be seen as different "strands" of democracy that could be tied together in various ways (some thicker than others), or they may be seen as different "lodestars" for guiding the death penalty toward democracy. In either case, discussions of the relationship between democracy and the death penalty in Japan have long been dominated by a narrow understanding of "democracy" that stresses its representative and participatory dimensions while marginalizing its legal and liberal ones. In most discussions, prosecutors, judges, lay judges, and victims are expected to participate in the death penalty system as representatives who are responsive to public opinion, but little is said about the relevance of legal and liberal values. In this constricted view of democracy, legal values such as fairness and due process get discounted or ignored, as do liberal values such as human dignity and the right to life. A richer understanding of democracy and the death penalty would not marginalize these legal and liberal values. It would recognize that many of Japan's core values are legal and liberal, and it would acknowledge that the death penalty often undermines them. A richer understanding would also realize that there is wisdom in moving beyond the "tough on crime" (genbatsuka) rhetoric that characterizes the culture of capital punishment in Japan, in order to be "smart on crime" (as discussed in Chapter 1, the death penalty does not deter homicide), and in order to respect the rights and dignity of all human beings - even those who have committed terrible crimes. ${ }^{29}$

The abolitions that have occurred in other developed democracies have expressed democratic values-including respect for human rights. I admire former Japanese Minister of Justice Chiba Keiko, who authorized the executions in 2010 , but in some ways she has misunderstood the relationship between democracy and death penalty reform-as have many other leaders in Japanese society. Chiba is continuing the struggle to abolish capital punishment, and I believe that, eventually, her side will prevail. After abolition, public support for capital punishment in Japan will probably decline (as it typically does after a country abolishes), Japanese lay judges will no longer be required to make life-and-death decisions, and Japanese victims and survivors will no longer feel the need

\footnotetext{
${ }^{29}$ For an eloquent defense of the right to life in the context of capital punishment, see Yasuda Yoshihiro, Shikei Bengonin: Ikiru to Iu Kenri (Kodansha, 2008).
} 
to beg state officials to kill the offenders who have caused their suffering. But until the day of abolition arrives, Japan's leaders need to confront a question that is as fundamental as it has been neglected: Is a reform which permanently deprives a state of the legal authority to kill its own citizens undemocratic?

\section{The Japanese Military and State Killing}

For most people most of the time, politics is less a matter of thinking deeply about democracy than it is a matter of social identity and partisan loyalty. ${ }^{30}$ Once this fact is recognized, politics can be seen as a parade of symbols and abstractions, and a political analysis will consider how people are placated and aroused by capital punishment.

In Japan, one overlooked aspect of death penalty symbolism is its relation to national defense. Democracy in Japan differs from democracy in other industrial nations because, in several respects, the Japanese state lacks authority to use military power and martial policies. ${ }^{31}$ Japan's postwar occupation created a government that is pacifist by constitutional promise (Article 9), pledged neither to threaten force nor use force in international disputes. Of course, Japan's Self Defense Forces are among the most technologically advanced armed forces in the world, and in 2018 the nation's aggregate military expenditures were the ninth highest in the world (just behind Germany and just ahead of South Korea). But when it feels threatened by hostile forces, Japan's constitutional commitment to pacifism removes an important means of governmental assertiveness. For a conservative government, this pacifism in military matters probably feels uncomfortably close to impotence. The restrictions on state killing imposed by Article 9 also help explain why Japan's conservative governments seem determined to carry out executions every year. The constraints of Article 9 make capital punishment a symbol of government power that the country's conservative leaders

\footnotetext{
${ }^{30}$ Jonathan Haidt, The Righteous Mind: Why Good People Are Divided by Politics and Religion (Pantheon, 2012).

${ }^{31}$ Sheila A. Smith, Japan Rearmed: The Politics of Military Power (Harvard University Press, 2019).
} 
seem loathe to relinquish, for to them it is a potent symbol of state sovereignty and of the proper relationship between the state and its subjects. ${ }^{32}$

Death sentences and executions in Japan declined steadily from the 1950s through the 1980s, but starting in the 1990s, the LDP put increased emphasis on capital punishment as an instrument of government, partly because of the absence of other martial options during a period in which many people (inside Japan and out) were calling on the country to develop a more assertive military posture in order to deal with new threats, such as the rise of China and the provocations of North Korea. Ironically, if the current LDP under Prime Minister Abe Shinzo succeeds in establishing a legal foundation for Japan's military to be more assertive abroad, conservative governments in the future may feel less compelled to promote the symbolic politics of capital punishment at home. There are countries (such as Costa Rica, Iceland, and Liechtenstein) that are pacifist both in military matters and with respect to capital punishment, but they are all significantly smaller than Japan, and they are far less influential internationally. None of them has a history of militarism anything like Japan's effort to create a "Greater East Asia Co-Prosperity Sphere" in the first half of the twentieth century, and most of them abolished the death penalty before they renounced the use of military force. No country as large and powerful as Japan has relinquished both the authority to use military force and the authority to use capital punishment. In this sense, Article 9 could be an obstacle to abolition in Japan. With respect to state killing, Japan is the mirror image of large countries in Europe (such as Germany and France) that retain the right to use military force while renouncing the right to use capital punishment. Time will tell how much longer Japan retains this distinctive status. For the time being, some Japan-watchers will continue to wonder why the Japanese state is permitted to kill its own citizens while it is forbidden to kill foreigners who threaten the nation's peace and welfare.

${ }^{32}$ David T. Johnson and Franklin E. Zimring, The Next Frontier: National Development, Political Change, and the Death Penalty in Asia (Oxford University Press, 2009), pp. 82-84. 


\section{IMAGINING ABOLITION}

Although the length of the struggle to end capital punishment in Japan is not known, the outcome seems inevitable in any but the most pessimistic view of the country's future. What circumstances could push Japan toward abolition? Let us imagine two possibilities.

One precipitating cause of abolition could be the clear revelation of a wrongful execution. Wrongful executions were a proximate cause of abolition in Britain in 1965, and in Japan following four death row exonerations in the 1980s, a moratorium on executions ensued for 40 months, from November 1989 to March 1993. But this route to abolition is far from certain, for there was widespread political and public apathy about the risks of wrongful execution after Hakamada Iwao was released from death row in 2014, some 46 years after he was condemned to death. Hakamada's case suggests that even a wrongful execution might result in little political resolve to end capital punishment-or even to substantially reform it. Moreover, prosecutors' resistance to a retrial for Hakamada suggests that they may be willing to deny strong evidence of a wrongful execution if and when it emerges. When power and rationality collide in a legal system, power usually prevails. ${ }^{33}$

A second scenario is that abolition in the United States could stimulate abolition in Japan. The retention of capital punishment in the world's most influential democracy has long helped to legitimate capital punishment in democracies such as Japan, Taiwan, and India. And some analysts believe a nation-wide American abolition could occur in the near future. Professors Carol and Jordan Steiker suggest that "the death penalty will not last much longer in the United States," mainly because many Justices on the U.S. Supreme Court have renounced capital punishment after repeatedly seeing their efforts fail to regulate it in a manner that is consistent with the principles and promises of the U.S. Constitution. ${ }^{34}$ Similarly, Professor Brandon Garrett has concluded that American capital punishment "is at the end of its rope." He believes it could be abolished "not in a matter of generations, but in a matter

\footnotetext{
${ }^{33}$ Bent Flyvbjerg, Rationality and Power: Democracy in Practice (University of Chicago Press, 1998).

${ }^{34}$ Carol S. Steiker and Jordan M. Steiker, Courting Death: The Supreme Court and Capital Punishment (The Belknap Press of Harvard University Press, 2016), pp. 4-5.
} 
of years." ${ }^{35}$ And in the U.S. Supreme Court's Glossip v. Gross decision (2015), Justice Stephen Breyer (joined by Justice Ruth Bader Ginsburg) stated that he believes it is "highly likely that the death penalty violates the Eighth Amendment" of the U.S. Constitution (prohibiting "cruel and unusual punishment"), because of three constitutional defects in its administration: unreliability in fact-finding, arbitrariness in application, and long delays between death sentences and executions that undermine the death penalty's main penological purposes (deterrence and retribution). Because of these chronic problems, Breyer called for a full briefing before the U.S. Supreme Court on the question of whether American capital punishment violates the Constitution. If such a briefing occurs before a Court with one more member who has serious concerns about the constitutionality of capital punishment than is the case at the time of this writing (July 2019), then American capital punishment could be abolished judicially, with repercussions for Japan and other retentionist nations who will have lost their American cover for a practice that has become increasingly difficult to defend in an era of human rights.

Regardless of the precipitating circumstance, abolition in Japan will occur only if elites push for it. Since conservatives have ruled the country for all but 3 of the last 64 years, we may wonder whether it is realistic to expect a conversion of this kind. Why would conservative policymakers embrace facts (about deterrence and wrongful convictions) they once shunned and adopt a position (abolition) they once abhorred, especially when changing minds on this subject is so difficult? Yet evidence from the United States, where many conservative leaders have turned against mass incarceration and capital punishment, suggests that the right circumstances could produce real reform in Japan too. ${ }^{36}$ One key to the conservative turn in America has been a major decline in crime over the past quarter-century, which made it easier for politicians to support "right on crime" policies instead of posturing as "tough on crime." In Japan, crime has been declining for more than a decade, and a once troubling turn toward penal

\footnotetext{
${ }^{35}$ Brandon Garret, End of Its Rope: How Killing the Death Penalty Can Revive Criminal Justice (Harvard University Press, 2017), p. 1.

${ }^{36}$ See, for example, David Dagan and Steven M. Teles, Prison Break: Why Conservatives Turned Against Mass Incarceration (Oxford University Press, 2016); and George F. Will, "Against the Death Penalty", Washington Post, September 28, 2018.
} 
populism has decelerated as incarceration rates have fallen. ${ }^{37}$ Time will tell more, but the decline of crime in what is already one of the world's safest societies could eventually prompt some of the country's conservative leaders to embrace "human rights" as a better frame for thinking about capital punishment in the twenty-first century than were the "crime control" and "atonement" frames that they routinely employed in previous decades. ${ }^{38}$

\section{Life After DeATH}

Let us also imagine what could change in Japan after capital punishment is abolished. This exercise will not only highlight several incentives for abolition; it will reveal some of the effects capital punishment has on other parts of Japan's criminal process. In terms of caseloads, capital punishment is a tiny part of Japan's criminal justice system. Less than 1 percent of all homicide offenders are sentenced to death, and homicide comprises less than $1 / 1000$ th of all Penal Code offenses. But capital punishment in Japan attracts far more attention and has many more consequences than its small size seems to warrant. Its disappearance could have at least four positive consequences for Japanese criminal justice, in addition to one consequence that could present a challenge for progressives. ${ }^{39}$

First, the death penalty in Japan promotes the practice of using extreme penal sanctions as status rewards for crime victims and their families. This serves a public relations function for capital punishment, by reducing the discomfort of citizens who worry about the state's power to kill. And pedagogically, the emphasis on punishment as a status reward for victims also implies that the more punishment is administered, the better off victims will be. The use of punishment as a status reward leads ever upward: it

\footnotetext{
${ }^{37}$ David T. Johnson, “Comparative Reflections on American Crime Declines", Berkeley Journal of Criminal Law, Issue 23-3 (Fall 2018), pp. 25-45.

${ }^{38}$ Mari Kita and David T. Johnson, "Framing Capital Punishment in Japan: Avoidance, Ambivalence, and Atonement", Asian Journal of Criminology, Vol. 9, No. 3 (September 2014), pp. 221-240.

${ }^{39}$ This analysis builds on the fine insights about life after the death penalty in the United States made by Brandon L. Garrett in End of Its Rope: How Killing the Death Penalty Can Revive Criminal Justice (Harvard University Press, 2017), pp. 212-260.
} 
is a one-way penal escalator. ${ }^{40}$ If 5 years is good, 10 years must be better, and 15 years must be better still. In this way, when criminal punishment is employed as a symbolic currency, the sky is the limit. If Japan abolishes the death penalty, this impulse toward penal inflation would probably decline.

Second, Japan's death penalty provides moral camouflage for other harsh criminal punishments-especially for the increasingly frequent practice of not releasing inmates who have been sentenced to an indefinite term of imprisonment (muki choeki). Japan does not have the penalty of life without parole, but in practice, persons sentenced to life with the possibility of parole serve extremely long sentences. As of the end of 2015,1835 persons were serving a life sentence, which was 15 times more than the number of persons detained on Japan's death rows. Almost half of those "lifers" were over age 60, and 12 had been in prison for more than 50 years. For the past decade, fewer than 10 persons under a life sentence have been released on parole each year. ${ }^{41}$ In reality, then, a life sentence in Japan often means "life without parole." If death disappeared as a sentencing option in Japan, a life sentence would be seen for what it is: an extremely severe criminal sanction. And without Japan's punishment ceiling set at death, parole might become a more realistic possibility for persons under a life sentence, and fewer citizens and survivors would have reason to complain that the non-capital sentence some heinous offender received is insufficiently severe.

Third, capital punishment in Japan diverts legal and judicial resources from the scrutiny of other criminal punishments and exercises of state power. Every nation has a limited number of lawyers with the political values and special skills required to defend against government excess in the prohibition of conduct and the punishment of crime. And in nations that retain capital punishment, the ultimate penalty is a magnet for lawyers concerned with excessive governmental power. In Japan, the criminal defense bar is small, and lawyers with this commitment are few and far between. When a significant proportion of the country's best attorneys concentrate

${ }^{40}$ Franklin E. Zimring and David T. Johnson, "The Dark at the Top of the Stairs: Four Destructive Influences of Capital Punishment on American Criminal Justice", in Joan Peterselia and Kevin R. Reitz, editors, The Oxford Handbook of Sentencing and Corrections (Oxford University Press, 2012), pp. 737-752.

${ }^{41}$ Kanji Muramatsu, David T. Johnson, and Koiti Yano, "The Death Penalty and Homicide Deterrence in Japan”, Punishment \& Society, Vol. 20, No. 4 (October 2018), p. 436 and p. 452 . 
on capital punishment, the result is a shortage of resources to monitor how state authority is exercised in other realms. Few informed observers believe Japan's bar performs adequately as a watchdog over state power (the task is large and the bar is small). Abolition of capital punishment would enable more progressive "cause lawyers" to confront criminal, constitutional, and regulatory issues where their help is sorely needed. ${ }^{42}$

Fourth, the end of capital punishment could bring political benefits to Japan, both domestically and internationally. At home, debates about criminal justice policy are frequently distorted by the power of capital punishment to command public attention and political concern. The abolition of capital punishment would eliminate this distortion and enable more frequent assessments of other criminal justice problems, such as the power of police, the discretion of prosecutors, and the deference of judges to law enforcement. Abolition would also reduce tensions between Japan and its international peers, especially the rich and democratic countries of Europe, which frequently complain about Japan's unwillingness to regard capital punishment as a human rights issue. ${ }^{43}$ And the disappearance of the death penalty would permit Japan to avoid claims of hypocrisy when it criticizes countries such as China and North Korea for their human rights failures. In the long run, the abolition of capital punishment in Japan could even change the nation's self-conception, from that of a country and culture that are ambivalent about state killing ("no" to war but "yes" to capital punishment) to one that stands consistently in support of life.

Research shows that American states that abolish capital punishment do not experience the "parade of horribles" that death penalty proponents predict. In the six American states that abolished between 2007 and 2014, murder rates in general did not increase, and neither did murder rates of police officers and correctional officials who were killed in the line of duty. ${ }^{44}$ There is little reason to suppose murder

${ }^{42}$ Daniel H. Foote, "Cause Lawyering in Japan: Reflections on the Case Studies and Justice Reform", in Patricia G. Steinhoff, editor, Going to Court to Change Japan: Social Movements and the Law in Contemporary Japan (University of Michigan Center for Japanese Studies, 2014), pp. 165-180.

${ }^{43}$ Sangmin Bae, "Friends Do Not Let Friends Execute: The Council of Europe and the International Campaign to Abolish the Death Penalty", International Politics, Vol. 45, No. 2 (March 2008), pp. 129-145.

${ }^{44}$ American Bar Association Committee on Capital Punishment, "Life After the Death Penalty: Implications for Retentionist States", August 14, 2017, pp. 1-34, at https://files. deathpenaltyinfo.org/legacy/files/pdf/Life-After-Death-Penalty_Transcript.pdf. 
rates in Japan would rise after abolition, but abolition could have another unwelcome effect, by removing the spotlight that capital punishment shines on the workings of Japanese criminal justice. Death is a special criminal sanction, even if Japanese courts are reluctant to recognize this as a matter of law. Its severity and its irrevocability evoke heightened concern about the possibility of justice miscarrying. One effect of capital punishment in Japan is public and media attention on problems in criminal justice that might otherwise escape notice. If death is abolished as a criminal sanction, Japanese progressives may need to find new ways to concentrate attention on the serious problems that afflict the criminal justice system more broadly. I believe abolition will eventually occur in Japan-and I hope concern about the country's wrongful conviction problem will increase in the era of life after death.

Open Access This chapter is licensed under the terms of the Creative Commons Attribution-NonCommercial-NoDerivatives 4.0 International License (http://creativecommons.org/licenses/by-nc-nd/4.0/), which permits any noncommercial use, sharing, distribution and reproduction in any medium or format, as long as you give appropriate credit to the original author(s) and the source, provide a link to the Creative Commons license and indicate if you modified the licensed material. You do not have permission under this license to share adapted material derived from this chapter or parts of it.

The images or other third party material in this chapter are included in the chapter's Creative Commons license, unless indicated otherwise in a credit line to the material. If material is not included in the chapter's Creative Commons license and your intended use is not permitted by statutory regulation or exceeds the permitted use, you will need to obtain permission directly from the copyright holder.

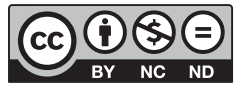

